\title{
Microwave-Assisted Hydrothermal Rapid Synthesis of Calcium Phosphates: Structural Control and Application in Protein Adsorption
}

\author{
Zhu-Yun Cai ${ }^{1, \dagger}$, Fan Peng ${ }^{1, \dagger}$, Yun-Peng Zi ${ }^{1}$, Feng Chen ${ }^{2, *}$ and Qi-Rong Qian ${ }^{1, *}$ \\ 1 Department of Orthopedics, Changzheng Hospital, Second Military Medical University, \\ Shanghai 200003, China; E-Mails: caizhuyun@126.com (Z.-Y.C.); maspf@163.com (F.P.); \\ ziyp0935@163.com (Y.-P.Z.)
}

2 State Key Laboratory of High Performance Ceramics and Superfine Microstructure, Shanghai Institute of Ceramics, Chinese Academy of Sciences, Shanghai 200050, China

$\dagger$ These authors contributed equally to this work.

* Authors to whom correspondence should be addressed; E-Mails: fchen@ mail.sic.ac.cn (F.C.); qianqr@163.com (Q.-R.Q.); Tel.: +86-21-52412602 (F.C.); +86-21-81885783 (Q.-R.Q.); Fax: +86-21-63528552 (Q.-R.Q.)

Academic Editors: Subramanian Tamil Selvan, Wolfgang J. Parak and Pablo del Pino

Received: 25 June 2015 / Accepted: 24 July 2015 / Published: 31 July 2015

\begin{abstract}
Synthetic calcium phosphate (CaP)-based materials have attracted much attention in the biomedical field. In this study, we have investigated the effect of $\mathrm{pH}$ values on $\mathrm{CaP}$ nanostructures prepared using a microwave-assisted hydrothermal method. The hierarchical nanosheet-assembled hydroxyapatite (HAP) nanostructure was prepared under weak acidic conditions ( $\mathrm{pH} 5$ ), while the HAP nanorod was prepared under neutral $(\mathrm{pH} 7)$ and weak alkali $(\mathrm{pH} 9)$ condition. However, when the $\mathrm{pH}$ value increases to 11 , a mixed product of HAP nanorod and tri-calcium phosphate nanoparticle was obtained. The results indicated that the $\mathrm{pH}$ value of the initial reaction solution played an important role in the phase and structure of the CaP. Furthermore, the protein adsorption and release performance of the as-prepared $\mathrm{CaP}$ nanostructures were investigated by using hemoglobin $(\mathrm{Hb})$ as a model protein. The sample that was prepared at $\mathrm{pH}=11$ and consisted of mixed morphologies of nanorods and nanoprisms showed a higher $\mathrm{Hb}$ protein adsorption capacity than the sample prepared at $\mathrm{pH} 5$, which could be explained by its smaller size and dispersed structure. The results revealed the relatively high protein adsorption capacity of the as-prepared $\mathrm{CaP}$
\end{abstract}


nanostructures, which show promise for applications in various biomedical fields such as drug delivery and protein adsorption.

Keywords: hydroxyapatite; microwave; nanostructure; drug delivery; protein adsorption

\section{Introduction}

Calcium phosphate $(\mathrm{CaP})$ materials have attracted much attention in the biomedical field, due to their excellent biocompatibility [1-3]. In native mineral tissue, nanostructured $\mathrm{CaP}$ can self-assemble into hierarchical structures to achieve excellent biological functions [4-6]. The synthetic CaP nanomaterials which have the similar chemical structure to the native mineral component in the bones and teeth of vertebrates are usually considered as an ideal biomaterial [7,8]. The synthetic CaP nanomaterials are deemed to be good for biocompatibility and bioactivity, and have been widely investigated in various applications, including drug delivery [9], protein adsorption [10], bone defect repair/tissue engineering [11,12], and other biomedical areas [13,14].

CaP-based materials include many kinds of chemical phases with different structure and properties, including octacalcium phosphate $\left(\mathrm{Ca}_{8}\left(\mathrm{HPO}_{4}\right)_{2}\left(\mathrm{PO}_{4}\right)_{4} \cdot 5 \mathrm{H}_{2} \mathrm{O}\right), \alpha$-tricalcium phosphate $\left(\alpha-\mathrm{Ca}_{3}\left(\mathrm{PO}_{4}\right)_{2}\right)$, $\beta$-tricalcium phosphate $\left(\beta-\mathrm{Ca}_{3}\left(\mathrm{PO}_{4}\right)_{2}\right)$, amorphous calcium phosphate $\left(\mathrm{Ca}_{x} \mathrm{H}_{y}\left(\mathrm{PO}_{4}\right)_{z} \cdot n \mathrm{H}_{2} \mathrm{O}, n=3-4.5\right.$, $\left.15 \%-20 \% \mathrm{H}_{2} \mathrm{O}\right)$, hydroxyapatite $\left(\mathrm{Ca}_{10}\left(\mathrm{PO}_{4}\right)_{6}(\mathrm{OH})_{2}\right)$, fluorapatite $\left(\mathrm{Ca}_{10}\left(\mathrm{PO}_{4}\right)_{6} \mathrm{~F}_{2}\right)$, and so on $[15,16]$. The crystal phase and morphology of synthetic $\mathrm{CaP}$ are strongly influenced by the preparation methods. In recent decades, a variety of $\mathrm{CaP}$ based materials with different morphologies, including nanorods, plate-like nanocrystals, nanoparticles, nanotubes and three-dimensional structures, have been prepared using different methods [8]. For example, various HAP materials have been prepared by solvothermal method, such as hierarchical microspheres [17], ordered arrays [18], nanoparticles [19], etc.

Compared to conventional heating methods, microwave heating technology is emerging as a form of rapid volumetric heating with advantages such as speed, shorter reaction time (usually in minutes), high efficiency, and energy savings [20]. Microwave heating has no thermal gradients throughout the bulk media and leads to efficient and uniform reactions [20,21]. Therefore, microwave heating technology has become a fast-growing area of research in synthetic chemistry, and has been widely used in the synthesis of various inorganic nanostructured materials including CaP biomaterials [22,23]. Up to now, various $\mathrm{CaP}$ nanostructured materials have been prepared by the microwave-assisted method in liquid phase, including nanoparticles and one-, two- and three-dimensional nanostructures [1,24-26].

The preparation, control over structure/size/morphology, properties and applications of $\mathrm{CaP}$ nanostructures have become a hot topic in the biomedical research field. Herein, we investigate the influence of $\mathrm{pH}$ value on the microwave-assisted hydrothermal rapid synthesis of $\mathrm{CaP}$ nanostructures. The HAP nanosheet-assembled hierarchical nanostructure, HAP nanorod and tri-calcium phosphate (TCP) nanoparticles were prepared with different $\mathrm{pH}$ values for the initial reaction solutions. Then, the as-prepared $\mathrm{CaP}$ nanostructures are explored for application in protein adsorption/release with hemoglobin $(\mathrm{Hb})$ as a model protein, which exhibits a relatively high protein adsorption capacity and sustained release properties. The as-prepared $\mathrm{CaP}$ nanostructures are promising for applications in various biomedical fields such as drug delivery and protein adsorption. 


\section{Results and Discussion}

As shown in Figure 1a, the product, which was prepared using a microwave-assisted hydrothermal method at $\mathrm{pH}=5$, consisted of HAP nanosheet-assembly flower-like hierarchical nanostructures, and the thickness of the HAP nanosheet was about $10 \mathrm{~nm}$. When the $\mathrm{pH}$ values of the initial reaction solution increase to 7 and 9 , the products prepared under the same conditons consisted of HAP nanorods with a length of about $100 \mathrm{~nm}$ (Figure 1b,c). However, the product consisted of mixed morphologies of nanorods and nanoprisms (Figure 1d) when the $\mathrm{pH}$ value of the initial reaction solution was further increased to 11 . These results indicate that the $\mathrm{pH}$ value has an important influence on the morphology and structure of $\mathrm{CaP}$ materials prepared with the microwave-assisted hydrothermal method.

The crystal phases of the CaP nanostructures prepared with the microwave-assisted hydrothermal method have been characterized by X-ray powder diffraction (XRD). As shown in Figure 2a-c, the products of samples A, B and C consisted of HAP (JCPDS No. 09-0432) when the pH values of the initial solution were adjusted to 5, 7 and 9. However, the as-prepared sample consisted of a mixture of HAP and tri-calcium phosphate (TCP, JCPDS No. 09-0169) (Figure 2d), when the pH value increase to 11 . These results indicate that the $\mathrm{pH}$ value of the reaction solution has an obvious effect on the crystal phase of CaP nanostructures prepared by microwave-assisted hydrothermal method.

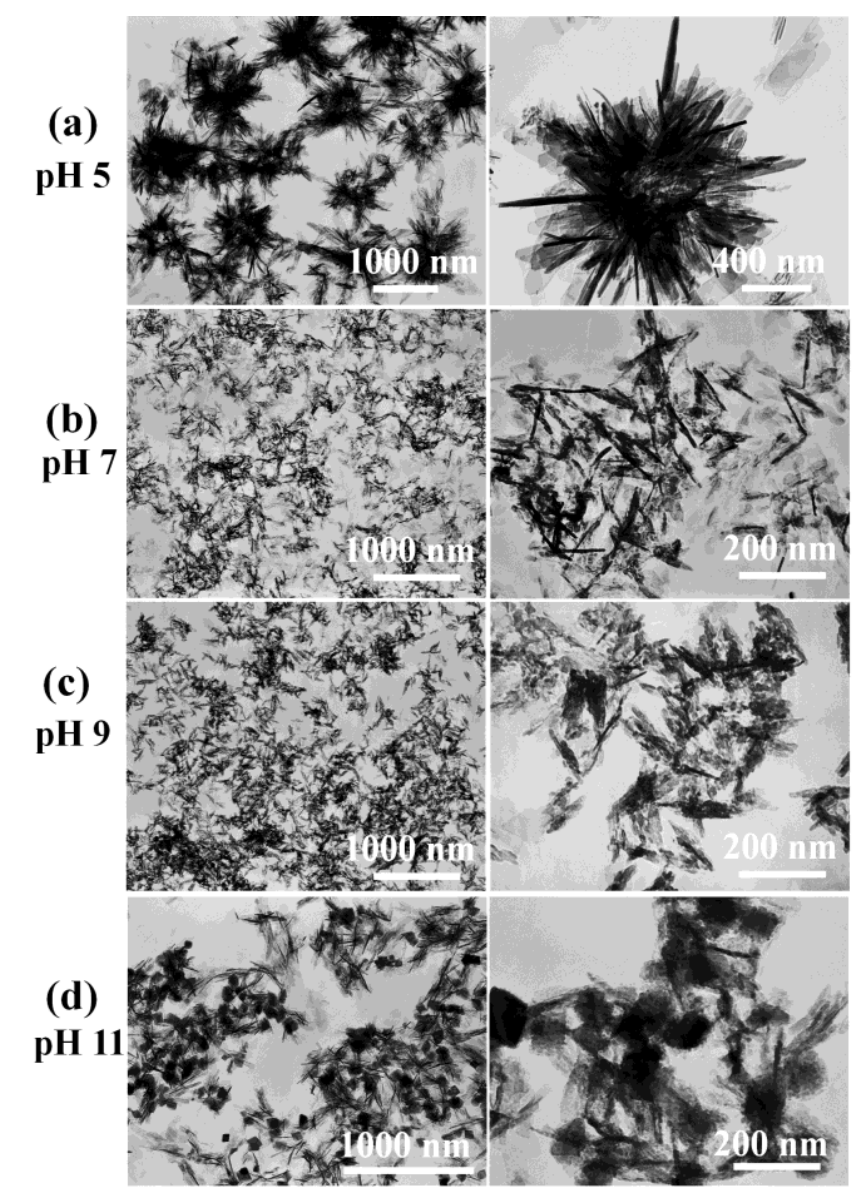

Figure 1. SEM of calcium phosphate nanostructures prepared with the microwave-assisted hydrothermal method under different $\mathrm{pH}$ values: (a) Sample A, $\mathrm{pH}=5$; (b) Sample B, $\mathrm{pH}=7$; (c) Sample C, $\mathrm{pH}=9$; (d) Sample D, $\mathrm{pH}=11$. 


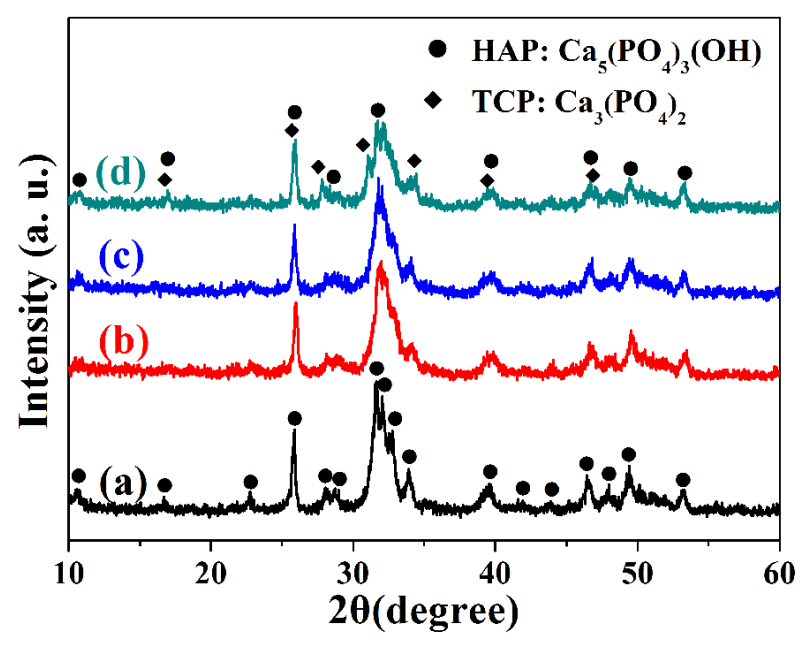

Figure 2. XRD patterns of calcium phosphate nanostructures prepared by microwave-assisted hydrothermal method under different $\mathrm{pH}$ values: (a) Sample A, $\mathrm{pH}=5$; (b) Sample B, $\mathrm{pH}=7$; (c) Sample C, $\mathrm{pH}=9$; (d) Sample D, $\mathrm{pH}=11$.

To further investigate the chemical properties of the samples, the Fourier transform infrared (FTIR) spectra of the as-prepared samples by microwave-assisted hydrothermal method under different $\mathrm{pH}$ values were measured. As shown in Figure 3, the FTIR spectra exhibit similar absorption bands. The broad absorption bands at around 3425 and $1635 \mathrm{~cm}^{-1}$ are assigned to the adsorbed water. The absorption band at about $3568 \mathrm{~cm}^{-1}$ arises from the hydroxyl group in HAP. The absorption bands at $1103,1034,962,603$ and $564 \mathrm{~cm}^{-1}$ are attributed to $\mathrm{PO}_{4}{ }^{3-}$ ions in samples. Among these peaks, the absorptions at 1103 and $1034 \mathrm{~cm}^{-1}$ are assigned to the $v_{3}$ vibrations of the $\mathrm{P}-\mathrm{O}$ bond of the phosphate group [27]. In addition, the samples exhibit the $v_{3}$ vibrational mode of carbonate ion at 1456 and $1419 \mathrm{~cm}^{-1}$, as well as the $v_{2}$ vibrational mode of carbonate ion at $874 \mathrm{~cm}^{-1}$, which is assigned to the $\left(\mathrm{CO}_{3}\right)^{2-}$ group of B-type HAP [28,29]. The absorption band at $1566 \mathrm{~cm}^{-1}$ is associated with the $\left(\mathrm{CO}_{3}\right)^{2-}$ substituted for $\mathrm{OH}^{-}$as A-type substitution [30]. The presence of $\left(\mathrm{CO}_{3}\right)^{2-}$ group in the HAP lattice may be derived from the dissolved $\mathrm{CO}_{2}$ from atmosphere.

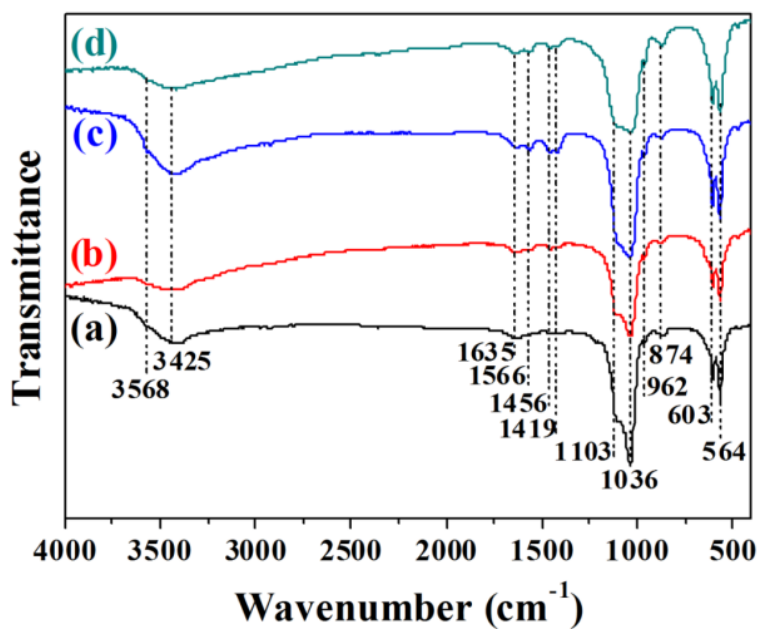

Figure 3. FTIR spectra of calcium phosphate nanostructures prepared by microwave-assisted hydrothermal method under different $\mathrm{pH}$ values: (a) Sample A, $\mathrm{pH}=5$; (b) Sample B, $\mathrm{pH}=7$; (c) Sample C, $\mathrm{pH}=9$; (d) Sample D, $\mathrm{pH}=11$. 
The schematic illustration for the preparation of $\mathrm{CaP}$ nanostructures is shown in Figure 4 . We investigate the influence of $\mathrm{pH}$ value on the $\mathrm{CaP}$ nanostructures synthesized by a microwave-assisted rapid hydrothermal method at $120{ }^{\circ} \mathrm{C}$ for $10 \mathrm{~min}$. The HAP nanosheet-assembled hierarchical nanostructures can be prepared under a weak acidic conditions ( $\mathrm{pH} 5)$, while the HAP nanorods can be prepared under a neutral ( $\mathrm{pH}$ 7) and weak alkali conditions ( $\mathrm{pH}$ 9). When the $\mathrm{pH}$ value increase to 11, the product consisted of a mixture of HAP nanorods and tri-calcium phosphate (TCP) nanoparticles. These results indicate that the $\mathrm{pH}$ value plays an important role in controlling the structure and chemical properties of $\mathrm{CaP}$ prepared with the microwave-assisted hydrothermal method.

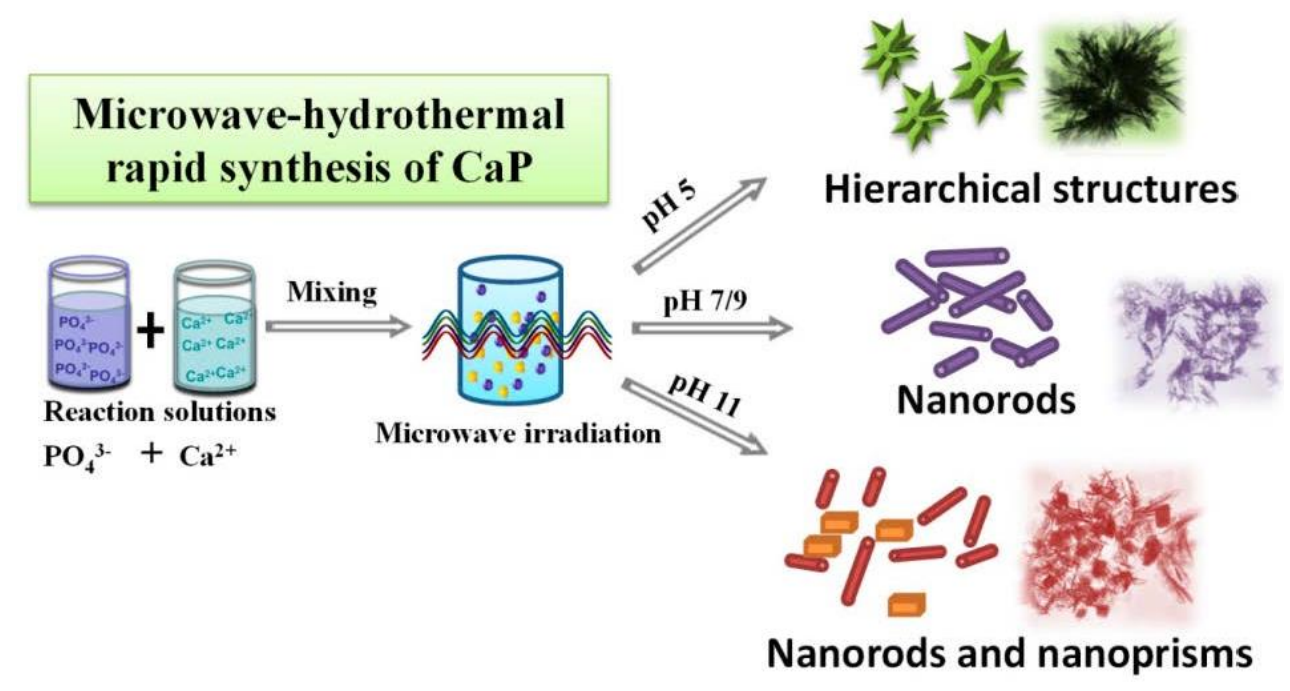

Figure 4. Schematic illustration for the synthesis of calcium phosphate nanostructures with the microwave-assisted hydrothermal method under different $\mathrm{pH}$ values.

A possible mechanism is proposed to illustrate the formation process of the HAP nanosheet-assembly flower-like hierarchical nanostructure. Due to the low $\mathrm{pH}$ value in the initial reaction solution, the amorphous $\mathrm{CaP}$ nuclei may appear due to the reaction in the precursor solution. Then, the temperature increased rapidly in a microwave-assisted hydrothermal environment. The amorphous $\mathrm{CaP}$ nuclei cannot guide the direction of crystallization and crystal growth at the initial stage [31]. Therefore, the products of spherulites composed of HAP nanosheets organized in a radial orientation are obtained, due to the disordered crystallization of amorphous $\mathrm{CaP}$ nuclei and crystal growth using the abundant $\mathrm{Ca}^{2+}$ and $\mathrm{PO}_{4}{ }^{3-}$ ions in the reaction solution, under microwave-assisted hydrothermal conditions.

On the other hand, the HAP nanorods are prepared when the $\mathrm{pH}$ values of the reaction solution increase to 7 and 9 . This result can be explained by the different reaction mechanism compared with the HAP nanosheet-assembly hierarchical nanostructure prepared with the microwave-assisted hydrothermal method at a lower $\mathrm{pH}$ value $(\mathrm{pH}=5)$. In the precursor solution with high $\mathrm{pH}$ values (7 and 9), a large number of $\mathrm{CaP}$ nuclei with low crystallinity may appear due to the reaction of abundant $\mathrm{Ca}^{2+}$ and $\mathrm{PO}_{4}{ }^{3-}$ ions in the initial reaction solution. Thereafter, when the reaction solutions are transformed to a microwave-assisted hydrothermal environment, the product of HAP nanorods can occur via a crystal growth process with the templates of these $\mathrm{CaP}$ nuclei, and there is a specific preferred growth direction along the $c$-axis of the hexagonal HAP. Therefore, the HAP nanorods can be prepared at the $\mathrm{pH}$ values of 7 and 9 . 
When the $\mathrm{pH}$ value is increased to 11 , the as-prepared $\mathrm{CaP}$ product consisted of a mixture of HAP nanorods and TCP nanoprisms. We propose that the presence of TCP phase in the product may be explained by the combined effect of the high $\mathrm{pH}$ value and the hydrothermal environment. In the precursor solution with high $\mathrm{pH}$ values $(\mathrm{pH}=11)$, the CaP nuclei with crystal phase of HAP and TCP may appear due to the reaction of abundant $\mathrm{Ca}^{2+}$ and $\mathrm{PO}_{4}{ }^{3-}$ ions. Then, the product of HAP nanorods and TCP nanoprisms can be formed through the crystal growth of these CaP nuclei in the microwave-assisted hydrothermal environment. The TCP and HA materials are usually selected and mixed to prepare composite materials which can be used as important biomaterials for bone defect repair and other biomedical fields, due to their high biocompatibility and controllable biodegradability [32,33]. In this study, the composite material of nanostructured TCP and HA can be directly and rapidly prepared with the microwave-assisted hydrothermal method under a lower temperature. This strategy may be favorable for the preparation of homogenized TCP/HA composite materials.

We have also investigated the protein adsorption performance of Sample A and Sample D by using $\mathrm{Hb}$ as a model protein. The $\mathrm{Hb}$ adsorption amounts for both Sample A and Sample D increase with increasing initial $\mathrm{Hb}$ concentration from 0.2 to $1.2 \mathrm{mg} \cdot \mathrm{mL}^{-1}$, and separately reach a plateau of 155 and $205 \mathrm{mg} \cdot \mathrm{g}^{-1}$ at a $\mathrm{Hb}$ concentration of $1.2 \mathrm{mg} \cdot \mathrm{mL}^{-1}$ (Figure $5 \mathrm{a}$ ). However, the $\mathrm{Hb}$ adsorption percentages decrease from $71 \%$ to $10 \%$ for Sample A, and decrease from $90 \%$ to $13 \%$ for Sample D, with increasing $\mathrm{Hb}$ initial concentration from 0.2 to $4.0 \mathrm{mg} \cdot \mathrm{mL}^{-1}$ (Figure $5 \mathrm{~b}$ ).
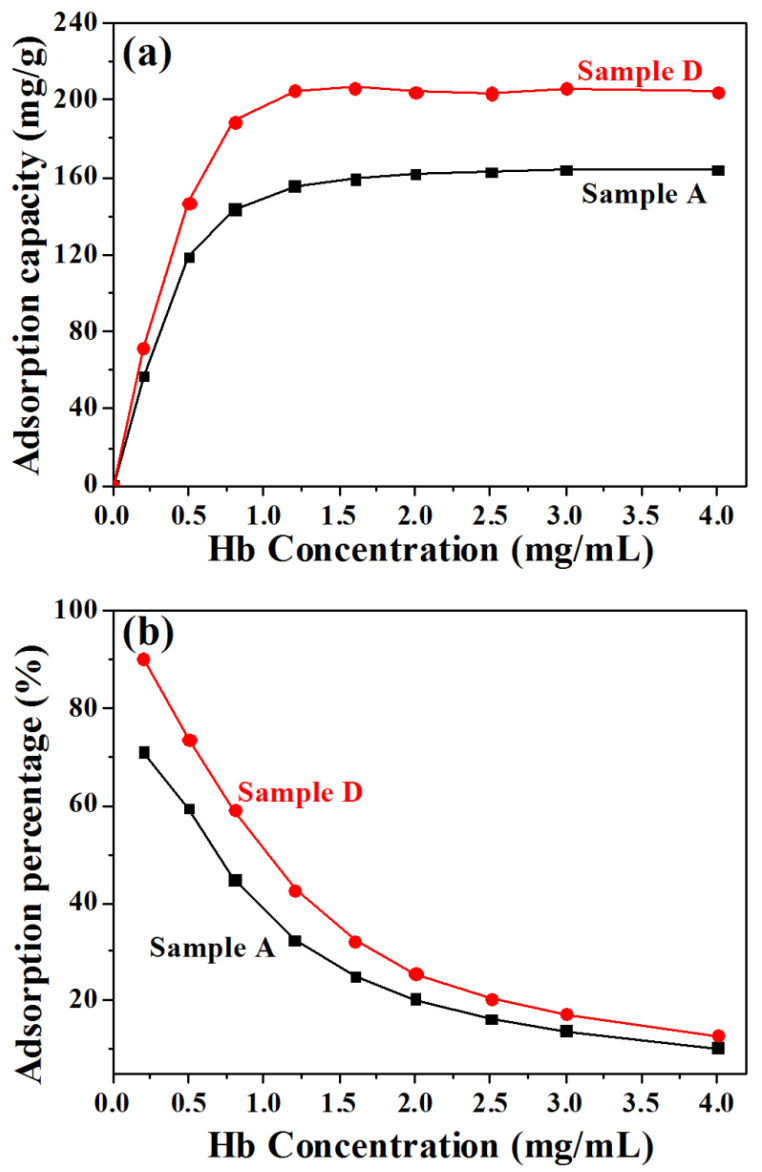

Figure 5. The $\mathrm{Hb}$ protein adsorption properties of Sample A (pH 5) and Sample D (pH 11). (a) $\mathrm{Hb}$ adsorption capacity as a function of initial $\mathrm{Hb}$ concentration; (b) $\mathrm{Hb}$ adsorption percentage as a function of initial $\mathrm{Hb}$ concentration. 
The high protein adsorption properties of the as-prepared $\mathrm{CaP}$ nanostructures can be explained by the native chemical properties of $\mathrm{CaP}$ based materials. The native bone tissue constructed by the $\mathrm{CaP}$ materials and collagen is a native reservoir for storing growth factors, fatty acids, and other biomolecules [34]. Therefore, we think CaP-based materials have the advantage of high adsorption capacity for a variety of biomolecules, due to a high binding affinity. Up to now, CaP based materials have been used as a delivery vehicle for various proteins, growth factors, antibiotics, macromolecules and so on [35-37].

The Langmuir adsorption model is used to calculate the maximum $\mathrm{Hb}$ adsorption capacity of the as-prepared $\mathrm{CaP}$ nanostructures:

$$
\begin{gathered}
q_{e}=\frac{q_{m} b c_{e}}{1+b c_{e}} \\
\frac{c_{e}}{q_{e}}=\frac{1}{q_{m} b}+\frac{c_{e}}{q_{m}}
\end{gathered}
$$

As shown in Equation (1), where $q_{e}\left(\mathrm{mg} \cdot \mathrm{g}^{-1}\right)$ is the amount of $\mathrm{Hb}$ protein adsorbed at equilibrium, $c_{e}\left(\mathrm{mg} \cdot \mathrm{mL}^{-1}\right)$ is the equilibrium concentration of the solution, $q_{m}\left(\mathrm{mg} \cdot \mathrm{g}^{-1}\right)$ is the maximum adsorption capacity that corresponds to complete monolayer coverage and $b$ is the equilibrium constant $\left(\mathrm{mL} \cdot \mathrm{mg}^{-1}\right)$, the Langmuir isothermal adsorption equation represents the relationship between $q_{e}$ and $c_{e}$. From Equation (2), one can see that the $c_{e} / q_{e}$ has a linear relationship with $c_{e}$. As shown in Figure 6, the experimental result also exhibited a good linear relationship between $c_{e} / q_{e}$ and $c_{e}$. According to the adsorption isotherms, the maximum $\mathrm{Hb}$ protein adsorption capacity $q_{m}$ of the Sample A and Sample D were 168.63 and $207.04 \mathrm{mg} \cdot \mathrm{g}^{-1}$, and the corresponding equilibrium constant $b$ were 12.1 and $36.9 \mathrm{~mL} \cdot \mathrm{mg}^{-1}$, respectively. The $\mathrm{Hb}$ protein adsorption capacity values of the Sample A $\left(155 \mathrm{mg} \cdot \mathrm{g}^{-1}\right)$ and Sample D (205 mg. $\mathrm{g}^{-1}$ ) measured from experiment are close to the calculated values (168.63 and $207.04 \mathrm{mg} \cdot \mathrm{g}^{-1}$ ) from the Langmuir adsorption model. Sample A was prepared with the microwave-assisted hydrothermal method at $\mathrm{pH}=5$ and consisted of HAP nanosheet-assembly flower-like hierarchical nanostructures. Meanwhile, Sample D, with a higher Hb protein adsorption capacity, was prepared with the same method at $\mathrm{pH}=11$ and consisted of mixed morphologies of nanorods and nanoprisms. The higher $\mathrm{Hb}$ protein adsorption capacity of Sample D may be explained by its smaller size and dispersed structure, compared with Sample A. The smaller size and dispersed structure may supply more adsorption sites for the protein molecules, and lead to the higher $\mathrm{Hb}$ protein adsorption capacity.

Figure $7 \mathrm{a}$ shows the $\mathrm{Hb}$ release behaviors of Hb-adsorbed Sample A and Sample D prepared in an $\mathrm{Hb}$ solution with a concentration of $2 \mathrm{mg} \cdot \mathrm{mL}^{-1}$. The cumulative $\mathrm{Hb}$ release percentages from the Hb-adsorbed Sample A in PBS can reach 18.6\%, 25.2\%, 32.8\% and 38.0\% at release times of 1, 2, 4 and $6 \mathrm{~h}$, respectively. Meanwhile, the cumulative $\mathrm{Hb}$ release percentages from the $\mathrm{Hb}$-adsorbed Sample D can reach to $20.2 \%, 26.5 \%, 37.3 \%$ and $42.3 \%$ at release times of $1,2,4$ and $6 \mathrm{~h}$, respectively. $\mathrm{The} \mathrm{Hb}$ release from both samples is rapid in the first several hours. After the initial rapid release stage, the $\mathrm{Hb}$ release rate can gradually decrease. The cumulative amounts of $\mathrm{Hb}$ released from Sample A and Sample D reach plateaus of $45 \%$ and $48 \%$ after $24 \mathrm{~h}$, respectively. Moreover, for both Sample A and Sample D, the cumulative amount of released Hb has a good linear relationship with the square root of the release time, which is shown in Figure $7 \mathrm{~b}$. This result indicates that Hb release from 
Hb-adsorbed Sample A and Sample D is essentially governed by a diffusion process according to the Higuchi model [38,39].

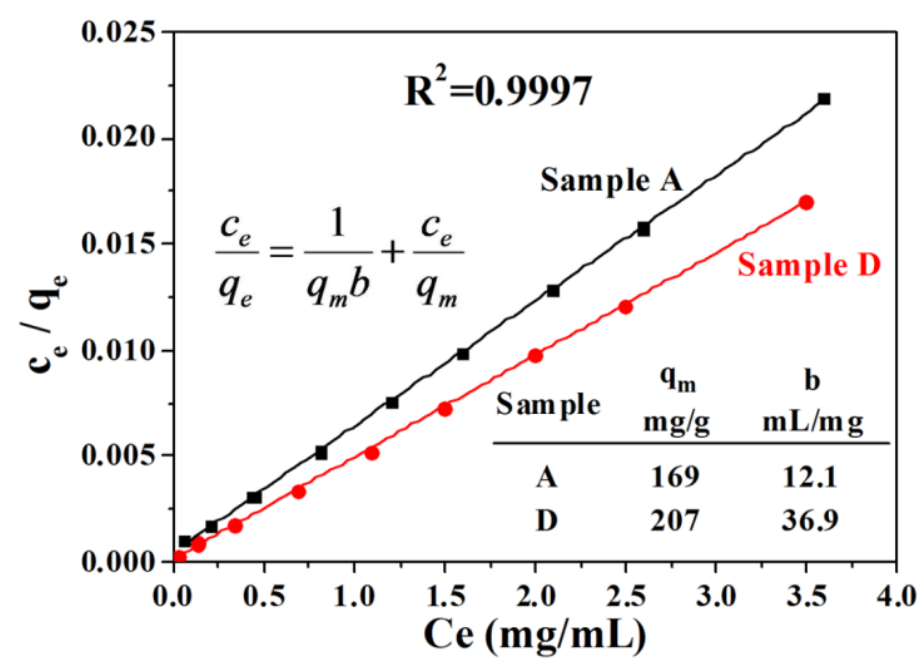

Figure 6. The $\mathrm{Hb}$ protein adsorption properties of Sample A ( $\mathrm{pH} 5)$ and Sample D (pH 11). The linear relationship between $c_{e} / q_{e}$ and $c_{e}$.
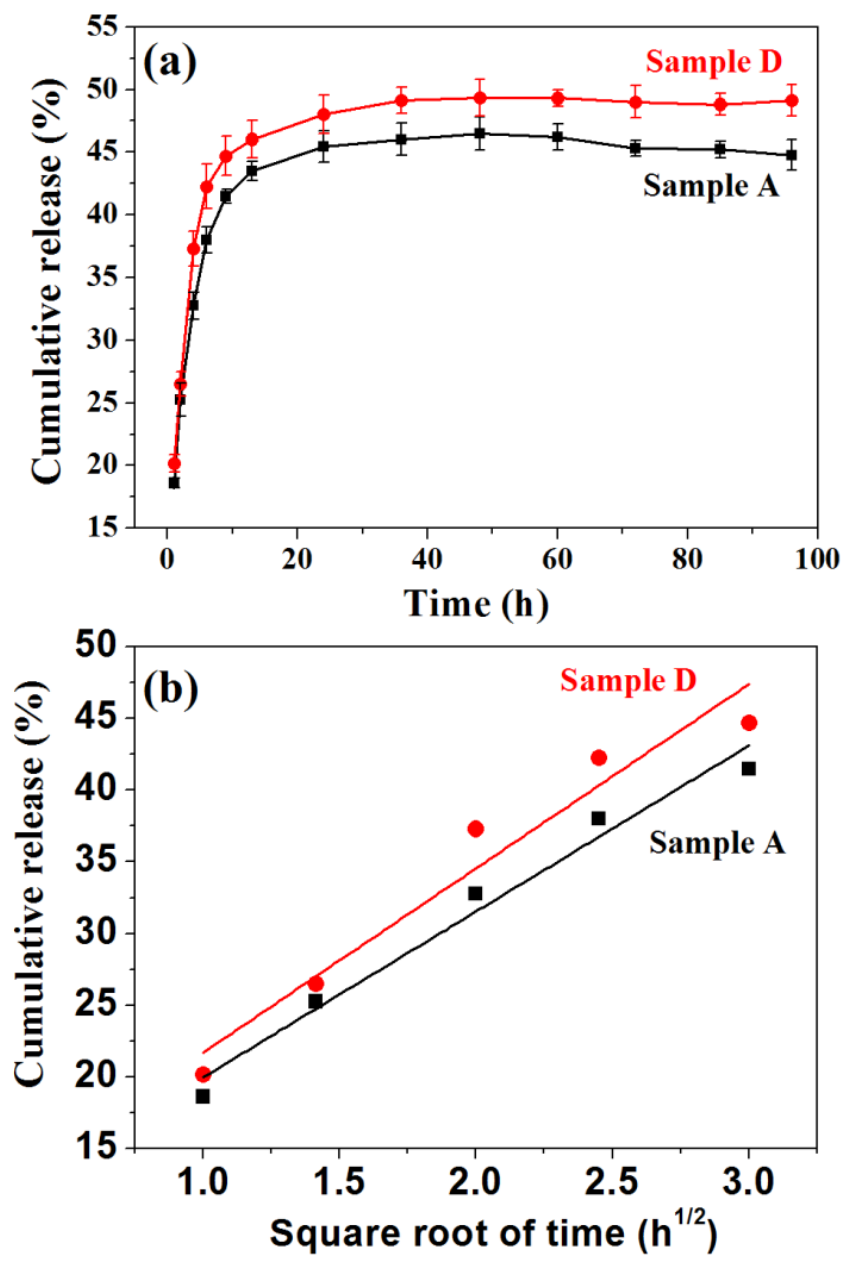

Figure 7. The $\mathrm{Hb}$ release properties of Sample A and Sample D. (a) Hb-release curve in PBS solution at different times; (b) cumulative Hb-release percentage as a function of the square root of the release time. 


\section{Experimental Section}

\subsection{Preparation of Calcium Phosphate Nanostructures}

In a typical experiment, $1.791 \mathrm{~g}$ of $\mathrm{Na}_{2} \mathrm{HPO}_{4} \cdot 12 \mathrm{H}_{2} \mathrm{O}$ was dissolved in $250 \mathrm{~mL}$ of deionized water to form Solution $\mathrm{A} ; 1.762 \mathrm{~g}$ of $\mathrm{Ca}\left(\mathrm{CH}_{3} \mathrm{COO}\right)_{2} \cdot \mathrm{H}_{2} \mathrm{O}$ and $0.26 \mathrm{~g}$ of 5-Fluorouracil was dissolved in $100 \mathrm{~mL}$ of deionized water to form Solution B. Thereafter, $10 \mathrm{~mL}$ of Solution B was added dropwise to $30 \mathrm{~mL}$ Solution A under magnetic stirring, and the $\mathrm{pH}$ values were adjusted to 5 (Sample A), 7 (Sample B), 9 (Sample C) and 11 (Sample D) by $1 \mathrm{M} \mathrm{HCl}$ or $1 \mathrm{M} \mathrm{NaOH}$ solution. Then, each resulting solution was put into an autoclave $(60 \mathrm{~mL})$, sealed and microwave-heated in a multimode-microwave oven (MDS-6, Sineo, Shanghai, China) to $120{ }^{\circ} \mathrm{C}$ and maintained at this temperature for 10 min under a heating power of $400 \mathrm{~W}$. The multimode-microwave oven used in this study was a commercial instrument for the microwave-assisted liquid phase reaction. The temperature/pressure and the heating power were controlled by the instrument. After cooling down to room temperature, the products were separated by centrifugation, washed with deionized water and ethanol several times, and then dried to powder at $60{ }^{\circ} \mathrm{C}$ for $24 \mathrm{~h}$. All of the chemicals used in the sample preparation were analytical grade, purchased from Sinopharm Chemical Reagent Co. (Shanghai, China), and used as received without further purification.

\subsection{Characterization of Samples}

The crystal phases of the as-prepared $\mathrm{CaP}$ samples were characterized using XRD recorded using a $\mathrm{X}$-ray diffractometer (Rigaku D/max $2550 \mathrm{~V}, \mathrm{Cu} \mathrm{K} \alpha$ radiation, $\lambda=1.54178 \AA$ ) (Rigaku Co., Tokyo, Japan). FTIR spectra were taken on a FTIR spectrometer (FTIR-7600, Lambda Scientific, Edwardstown, Australia) using $\mathrm{KBr}$ pellets. The micrographs were taken with transmission electron microscope (TEM, Hitachi H-800, Tokyo, Japan).

\subsection{Protein Adsorption and Release Properties}

Hemoglobin $(\mathrm{Hb})$ was chosen as a model protein for our investigation, and was purchased from Sangon Biotech (Shanghai, China). The protein-adsorption experiments at different protein concentrations were performed as follows: $5 \mathrm{mg}$ of powdered $\mathrm{CaP}$ samples which were prepared with the microwave-assisted hydrothermal method under $\mathrm{pH}$ values of 5 (Sample A) and 11 (Sample D) were immersed in aqueous solutions that contained various concentrations of the protein ( $2 \mathrm{~mL}, 0.2-4.0 \mathrm{mg} \cdot \mathrm{mL}^{-1}$ ). Each solution was treated ultrasonically for $10 \mathrm{~min}$, and shaken at a constant rate $(120 \mathrm{rpm})$ at $37{ }^{\circ} \mathrm{C}$ for $4 \mathrm{~h}$. Then, the solution was centrifuged and the amount of protein in the supernatant was measured by UV/Vis absorption at a wavelength of $405 \mathrm{~nm}$ using a UV-Vis spectrophotometer (UV-2300, Techcomp, Shanghai, China).

For the in vitro protein release, $80 \mathrm{mg}$ of powdered Sample A and sample D were immersed in an aqueous solution of $\mathrm{Hb}\left(2 \mathrm{mg} \cdot \mathrm{mL}^{-1}, 20 \mathrm{~mL}\right)$. Then, the solution was treated ultrasonically for $10 \mathrm{~min}$, and continuously shaken in a sealed vessel at $37{ }^{\circ} \mathrm{C}$ for $4 \mathrm{~h}$, followed by centrifugation and freeze drying to obtain the protein-adsorbed samples. The in vitro protein-release experiments were performed as follows: The powdered samples $(8 \mathrm{mg})$ were immersed in phosphate buffered saline 
(PBS) solution $(8 \mathrm{~mL})(\mathrm{pH} 7.4)$ at $37^{\circ} \mathrm{C}$ with constant shaking $(140 \mathrm{rpm})$. The protein-release solution $(400 \mathrm{~mL})$ was withdrawn for $\mathrm{UV}-\mathrm{V}$ is absorption analysis at given time intervals, and replaced with the same volume of fresh $\mathrm{PBS}\left(37^{\circ} \mathrm{C}, \mathrm{pH} 7.4\right)$.

\section{Conclusions}

Synthetic CaP materials have been considered ideal biomaterials due to their similar chemical structure to the native mineral components in the bones and teeth of vertebrates. Therefore, the preparation, control over structure/size/morphology, properties and applications of synthetic $\mathrm{CaP}$ nanostructures have become a hot topic. Herein, we have investigated the important role of $\mathrm{pH}$ value on the crystal phase and morphology of the $\mathrm{CaP}$ nanostructures prepared with the microwave-assisted hydrothermal method. The HAP nanosheet-assembled hierarchical nanostructures can be prepared under weak acidic conditions ( $\mathrm{pH}$ 5), while the HAP nanorods can be prepared under neutral ( $\mathrm{pH} 7$ ) and weak alkali conditions ( $\mathrm{pH} 9)$. When the $\mathrm{pH}$ value is increased to 11 , the product consisted of a mixture of HAP nanorods and TCP nanoparticles. We can therefore regulate the morphology and structural properties of the $\mathrm{CaP}$ by adjusting the $\mathrm{pH}$ value. In addition, the as-prepared $\mathrm{CaP}$ nanostructures were investigated for potential applications in protein adsorption by $\mathrm{Hb}$ as a model protein. The sample which was prepared at $\mathrm{pH}=11$ and consisted of mixed morphologies of nanorods and nanoprisms showed a higher $\mathrm{Hb}$ protein adsorption capacity than the sample prepared at $\mathrm{pH} 5$, which could be explained by the smaller size and dispersed structure. The experimental $\mathrm{Hb}$ protein adsorption capacity values of the samples prepared at $\mathrm{pH} 5$ and $\mathrm{pH} 11$ were $155 \mathrm{mg} \cdot \mathrm{g}^{-1}$ and $205 \mathrm{mg} \cdot \mathrm{g}^{-1}$, which are close to the calculated values $\left(168.63 \mathrm{mg} \cdot \mathrm{g}^{-1}\right.$ and $207.04 \mathrm{mg} \cdot \mathrm{g}^{-1}$ ) from the Langmuir adsorption model. The results reveal the as-prepared $\mathrm{CaP}$ nanostructures have a relatively high protein adsorption capacity, which is promising for applications in various biomedical fields such as drug delivery and protein adsorption.

\section{Acknowledgments}

The financial support from the National Natural Science Foundation of China $(51472259,81171727)$ and the Science and Technology Commission of Shanghai (13JC1407300) is gratefully acknowledged.

\section{Author Contributions}

Zhu-Yun Cai performed experimental work and analyzed the experimental data, Fan Peng and Yun-Peng Zi performed experimental work, and Feng Chen and Qi-Rong Qian analyzed the experimental data and wrote the manuscript.

\section{Conflicts of Interest}

The authors declare no conflict of interest.

\section{References}

1. Lin, K.L.; Wu, C.T.; Chang, J. Advances in synthesis of calcium phosphate crystals with controlled size and shape. Acta Biomater. 2014, 10, 4071-4102.

2. LeGeros, R.Z. Calcium phosphate-based osteoinductive materials. Chem. Rev. 2008, 108, 4742-4753. 
3. Dorozhkin, S.V.; Epple, M. Biological and medical significance of calcium phosphates. Angew. Chem. Int. Ed. 2002, 41, 3130-3146.

4. Weiner, S.; Wagner, H.D. The material bone: Structure mechanical function relations. Annu. Rev. Mater. Sci. 1998, 28, 271-298.

5. Rubin, M.A.; Jasiuk, L.; Taylor, J.; Rubin, J.; Ganey, T.; Apkarian, R.P. Tem analysis of the nanostructure of normal and osteoporotic human trabecular bone. Bone 2003, 33, 270-282.

6. Pasteris, J.D.; Wopenka, B.; Valsami-Jones, E. Bone and tooth mineralization: Why apatite? Elements 2008, 4, 97-104.

7. Dorozhkin, S.V. Nanosized and nanocrystalline calcium orthophosphates. Acta Biomater. 2010, 6, 715-734.

8. Chen, F.; Zhu, Y.J.; Wu, J.; Huang, P.; Cui, D.X. Nanostructured calcium phosphates: Preparation and their application in biomedicine. Nano. Biomed. Eng. 2012, 4, 41-49.

9. Feng, D.S.; Shi, J.; Wang, X.J.; Zhang, L.; Cao, S.K. Hollow hybrid hydroxyapatite microparticles with sustained and ph-responsive drug delivery properties. $R S C A d v . \mathbf{2 0 1 3}, 3$, 24975-24982.

10. Chen, F.; Li, C.; Zhu, Y.J.; Zhao, X.Y.; Lu, B.Q.; Wu, J. Magnetic nanocomposite of hydroxyapatite ultrathin nanosheets/ $\mathrm{Fe}_{3} \mathrm{O}_{4}$ nanoparticles: Microwave-assisted rapid synthesis and application in pH-responsive drug release. Biomater. Sci. 2013, 1, 1074-1081.

11. Zhou, H.; Lee, J. Nanoscale hydroxyapatite particles for bone tissue engineering. Acta Biomater. 2011, 7, 2769-2781.

12. He, C.L.; Zhang, F.; Cao, L.J.; Feng, W.; Qiu, K.X.; Zhang, Y.Z.; Wang, H.S.; Mo, X.M.; Wang, J.W. Rapid mineralization of porous gelatin scaffolds by electrodeposition for bone tissue engineering. J. Mater. Chem. 2012, 22, 2111-2119.

13. Chen, F.; Zhu, Y.J. Multifunctional calcium phosphate nanostructured materials and biomedical applications. Curr. Nanosci. 2014, 10, 465-485.

14. Chen, F.; Huang, P.; Zhu, Y.J.; Wu, J.; Zhang, C.L.; Cui, D.X. The photoluminescence, drug delivery and imaging properties of multifunctional $\mathrm{Eu}^{3+} / \mathrm{Gd}^{3+}$ dual-doped hydroxyapatite nanorods. Biomaterials 2011, 32, 9031-9039.

15. Dorozhkin, S.V. Bioceramics of calcium orthophosphates. Biomaterials 2010, 31, 1465-1485.

16. Dorozhkin, S.V. Calcium orthophosphate-based biocomposites and hybrid biomaterials. J. Mater. Sci. 2009, 44, 2343-2387.

17. Long, T.; Guo, Y.P.; Liu, Y.Z.; Zhu, Z.A. Hierarchically nanostructured mesoporous carbonated hydroxyapatite microspheres for drug delivery systems with high drug-loading capacity. RSC Adv. 2013, 3, 24169-24176.

18. Chen, F.; Zhu, Y.J.; Wang, K.W.; Zhao, K.L. Surfactant-free solvothermal synthesis of hydroxyapatite nanowire/nanotube ordered arrays with biomimetic structures. CrystEngComm 2011, 13, 1858-1863.

19. Kandori, K.; Kuroda, T.; Togashi, S.; Katayama, E. Preparation of calcium hydroxyapatite nanoparticles using microreactor and their characteristics of protein adsorption. J. Phys. Chem. B 2011, 115, 653-659.

20. Zhu, Y.J.; Chen, F. Microwave-assisted preparation of inorganic nanostructures in liquid phase. Chem. Rev. 2014, 114, 6462-6555. 
21. Qi, C.; Zhu, Y.J.; Cheng, G.F.; Ruan, Y.J.; Ding, G.J.; Sun, T.W.; Chen, F.; Wu, J. Microwave-assisted rapid synthesis of magnesium phosphate hierarchical structures using adenosine 5'-triphosphate disodium salt as a phosphorus source. Mater. Lett. 2015, 140, 79-82.

22. Ma, M.G.; Zhu, J.F.; Jia, N.; Li, S.M.; Sun, R.C.; Cao, S.W.; Chen, F. Rapid microwave-assisted synthesis and characterization of cellulose-hydroxyapatite nanocomposites in $N, N$-dimethylacetamide solvent. Carbohyd. Res. 2010, 345, 1046-1050.

23. Jia, N.; Li, S.M.; Ma, M.G.; Sun, R.C. Rapid microwave-assisted fabrication of cellulose/F-substituted hydroxyapatite nanocomposites using green ionic liquids as additive. Mater. Lett. 2012, 68, 44-46.

24. Zhang, D.Y.; Luo, H.M.; Zheng, L.W.; Wang, K.J.; Li, H.X.; Wang, Y.; Feng, H.X. Utilization of waste phosphogypsum to prepare hydroxyapatite nanoparticles and its application towards removal of fluoride from aqueous solution. J. Hazard. Mater. 2012, 241, 418-426.

25. Lak, A.; Mazloumi, M.; Mohajerani, M.S.; Zanganeh, S.; Shayegh, M.R.; Kajbafvala, A.; Arami, H.; Sadrnezhaad, S.K. Rapid formation of mono-dispersed hydroxyapatite nanorods with narrow-size distribution via microwave irradiation. J. Am. Ceram. Soc. 2008, 91, 3580-3584.

26. Kumar, G.S.; Girija, E.K. Flower-like hydroxyapatite nanostructure obtained from eggshell: A candidate for biomedical applications. Ceram. Int. 2013, 39, 8293-8299.

27. Cao, H.; Zhang, L.; Zheng, H.; Wang, Z. Hydroxyapatite nanocrystals for biomedical applications. J. Phys. Chem. C 2010, 114, 18352-18357.

28. Jevtić, M.; Mitrić, M.; Škapin, S.; Jančar, B.; Ignjatović, N.; Uskoković, D. Crystal structure of hydroxyapatite nanorods synthesized by sonochemical homogeneous precipitation. Cryst. Growth Des. 2008, 8, 2217-2222.

29. Qi, C.; Zhu, Y.J.; Zhao, X.Y.; Zhao, J.; Chen, F.; Cheng, G.F.; Ruan, Y.J. High surface area carbonate apatite nanorod bundles: Surfactant-free sonochemical synthesis and drug loading and release properties. Mater. Res. Bull. 2013, 48, 1536-1540.

30. Wang, Y.C.; Yao, A.H.; Huang, W.H.; Wang, D.P.; Zhou, J. In situ fabrication of hollow hydroxyapatite microspheres by phosphate solution immersion. J. Cryst. Growth 2011, 327, 245-250.

31. Pan, H.; Liu, X.Y.; Tang, R.; Xu, H.Y. Mystery of the transformation from amorphous calcium phosphate to hydroxyapatite. Chem. Commun. 2010, 46, 7415-7417.

32. Wang, Y.; Ni, M.; Tang, P.F.; Li, G. Novel application of HA-TCP biomaterials in distraction osteogenesis shortened the lengthening time and promoted bone consolidation. J. Orthop. Res. 2009, 27, 477-482.

33. Detsch, R.; Mayr, H.; Ziegler, G. Formation of osteoclast-like cells on HA and TCP ceramics. Acta Biomater. 2008, 4, 139-148.

34. Uskokovic, V.; Uskokovic, D.P. Nanosized hydroxyapatite and other calcium phosphates: Chemistry of formation and application as drug and gene delivery agents. J. Biomed. Mater. Res. B 2011, 96, 152-191.

35. Morcol, T.; Nagappan, P.; Nerenbaum, L.; Mitchell, A.; Bell, S.J.D. Calcium phosphate-PEG-insulin-casein (CAPIC) particles as oral delivery systems for insulin. Int. J. Pharm. 2004, 277, 91-97.

36. Matsumoto, T.; Okazaki, M.; Inoue, M.; Yamaguchi, S.; Kusunose, T.; Toyonaga, T.; Hamada, Y.; Takahashi, J. Hydroxyapatite particles as a controlled release carrier of protein. Biomaterials 2004, 25, 3807-3812.

37. Joosten, U.; Joist, A.; Frebel, T.; Brandt, B.; Diederichs, S.; von Eiff, C. Evaluation of an in situ setting injectable calcium phosphate as a new carrier material for gentamicin osteomyelitis: Studies in the treatment of chronic in vitro and in vivo. Biomaterials 2004, 25, 4287-4295. 
38. Higuchi, T. Mechanism of sustained-action medication-theoretical analysis of rate of release of solid drugs dispersed in solid matrices. J. Pharm. Sci. 1963, 52, 1145-1149.

39. Andersson, J.; Rosenholm, J.; Areva, S.; Linden, M. Influences of material characteristics on ibuprofen drug loading and release profiles from ordered micro- and mesoporous silica matrices. Chem. Mater. 2004, 16, 4160-4167.

(C) 2015 by the authors; licensee MDPI, Basel, Switzerland. This article is an open access article distributed under the terms and conditions of the Creative Commons Attribution license (http://creativecommons.org/licenses/by/4.0/). 